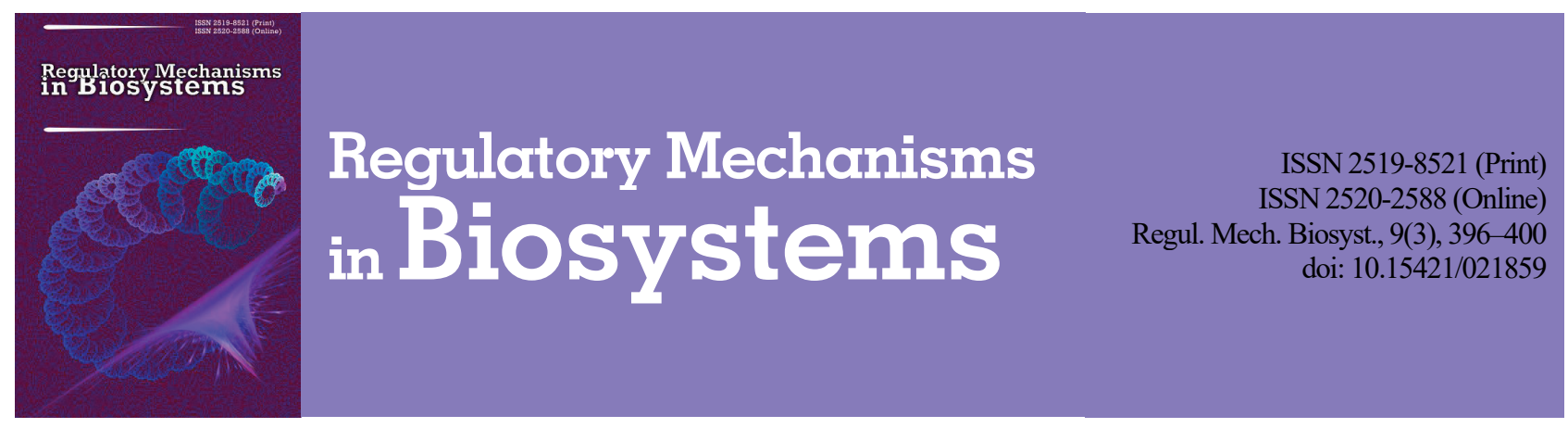

\title{
Bile acids from bile of rats of different sexes under testosterone
}

\author{
I. S. Chernuha, Y. M. Reshetnik, A. M. Liashevych, S. P. Veselsky, M. Y. Makarchuk \\ Taras Shevchenko National University of Kyiv, Kyiv, Ukraine
}

Article info

Received 19.06.2018

Received in revised form 15.07.2018

Accepted 17.07.2018

Taras Shevchenko National

University of Kyiv,

Glushkova st., 2

Kyiv, 03022, Ukraine.

Tel.: +38-068-623-87-48.

E-mail:

chernuhairina17@gmail.com Chernuha, I. S., Reshetnik, Y. M., Liashevych, A. M., Veselsky, S. P., \& Makarchuk, M. Y. (2018). Bile acids from bile of rats
of different sexes under testosterone. Regulatory Mechanisms in Biosystems, 9(3), 396-400. doi:10.15421/021859

Among the various functions of the liver, the formation of bile plays an important role. The optimal physiological ratio of bile components and the content of testosterone in the blood depend on various factors that can cause biliary system dysfunction and secretion. In experiments on different-sex rats, changes in bile acid contents of bile under the influence of testosterone propionate, which was injected intramuscularly $0.7 \mathrm{mg} / \mathrm{kg}$, for 5 days were investigated. With the method of thin-layer chromatography, the basic fractions of bile acids conjugated in the bile were defined - taurocholic, taurochenodeoxycholic and taurodeoxycholic, glycocholic, glycochenodeoxycholic and glycodeoxycholic and free - cholic, chenodeoxycholic and deoxycholic acids. Conjugation rates were calculated (the ratio of the sum of conjugated cholates to the amount of free ones) and hydroxylation (ratio of the sum of trihydroxycholate bile acids to the sum of dihydroxycholanic) bile acids. In the bile of female rats almost all concentrations of cholates increased, except glycochenodeoxycholic and glycodeoxycholic acids. The calculated conjugation index on the whole did not undergo significant changes, but the hydroxylation factor increased, which may indicate an intensification of bile acid biosynthesis by neutral means, which is realized by $7 \alpha$-hydroxylation of cholesterol. Under the influence of the hormone in male rats, the content of conjugated bile acids increased, and as for the free ones - a multidirectional effect of testosterone is observed, in particular, the concentration of cholic acid significantly decreased, indicating the activation of the poly-enzyme systems providing its conjugation with glycine and taurine. In connection with the wide use of the drug testosterone propionate and in view of its identified effects on the bile acid contents of the course of intramuscular administration, it is advisable to investigate the effect of this drug on the productive capacity of the liver.

Keywords: liver; cholates; conjugation index; hydroxylation index; testosterone propionate.

\section{Introduction}

In recent decades, there has been a tendency to increase in hepatobiliary pathology (Schirmer et al., 2005; Wang et al., 2008). Dysfunctional disorders of the biliary tract are found in most of the Ukrainian population, and the number of patients is steadily increasing (Gerbina et al., 2017). The liver is involved in metabolism of a number of hormones, therefore its disease may be accompanied by further hormonal disorders (Tomych, 2015). In particular, inflammatory processes in the liver affect metabolism of sex steroids, and may also suppress their binding with receptors throughout the whole body (Lee et al., 2017). Research has shown the complex relation of sex hormones with the liver, because it plays a role of mediator in a number of systemic effects on human and animal organisms (Klimyuk et al., 2010). Thus significant sex differences in liver functioning and metabolism discovered by many physiologists, suggest sex differentiation of liver functions (Rozen et al., 1991).

Recently, interest in the role of androgens in the development of obesity and obesity-related diseases such as diabetes, atherosclerosis and hypertension has increased. Testosterone regulates almost all intracellular transduction pathways directly involved in the metabolism of glucose and lipids, including key exchange enzymes (Bhandarkar et al., 2018; Yabiku et al., 2018; Yin et al., 2018; Palmisano et al., 2018). In particular, it has been shown that testosterone propionate changes lipid content of the bile of rats of different sex, that is, it affects the liver secretion function (Chernuha et al., 2017).

Medical studies indicate that cholelithiasis is more common in women than in men. It should be noted that Europeans are characterized by the formation of gallstones of a cholesterol nature. Women undergo the risk of their increase by physiologic rise in estrogen concentrations, which can be observed during pregnancy, the use of hormonal contraceptives and hormone substitution therapy in postmenopausal women (Novacek, 2006; Borovets et al., 2016). However, among men the number of hepatobiliary diseases is also increasing. The etiologies of their occurrence are nutrition and exogenous factors. Interestingly, the use of ethanol increases density of estrogen receptors in liver cells, which is believed to be a mechanism of feminization and the development of liver disease in alcoholism. There is also evidence that non-alcohol fatty liver disease is more common in men. Consequently, sex steroids are likely to play a role in its development. It is known that estrogens provide lipid homeostasis of the liver, and since androgens are predecessors of estrogen, then deviations in their ratio lead to pathological consequences (Boyer, 2013; Borovets et al., 2016; Mintziori et al., 2017).

The study of sex differences in the regulation of the bile-secretion function is considered as one of the most important trends in hepatology. And, since sex steroids are able to regulate the bile secretion function of the liver, their deficiency or excess can play a key role in the appearance of cholesterol gallstones (Ohshima et al., 1996). Therefore, nowadays considerable attention is paid to the study of the role of androgens in the development of pathologies of the hepatobiliary system. Intersexual differences in the formation of bile formation in liver tissue necessitate thorough experimental research on the effects of testosterone through various tests on the bile composition and the ratio of hepatitis secretion fractions in persons of different sex. And, because testosterone propionate is usually used intramuscularly for the treatment of a number of diseases, the purpose of our work is to detect the effect of the hormone on the bile acid composition of liver secretion of rats of both sexes. 


\section{Materials and methods}

Experiments were carried out on 39 white non-breeding rats weighing $180-230 \mathrm{~g}$. The study of the bile-secretion function of rats of both sexes was conducted in an acute experiment. The animals were kept in the accredited vivarium of the NSC "Institute of Biology and Medicine" of Kyiv Taras Shevchenko National University. All experiments were carried out in accordance with existing international and national requirements for the humane treatment of experimental animals.

The animals under investigation (males $n=9$; females $n=9$ ) were injected with a dose of $0.7 \mathrm{mg} / \mathrm{kg}$ body weight testosterone propionate for 5 days intramuscularly. The control group of male rats $(n=10)$ and females $(n=11)$ were daily injected intramuscularly with a solvent in the same volume as the amount of testosterone solution which each animal in the experimental group received daily for five days. For five days, the animals under study were kept in vivariums in four plastic specialized cells with a lattice iron lid in natural light, at a steady-state temperature regime and received a standard diet (feed for laboratory rats Vitamix, Ukraine) with free access to water.

Prior to surgical intervention, each animal was weighed and labeled. Sodium thiopental was used as an anesthetic in a dose of $60 \mathrm{mg} / \mathrm{kg}$ body weight of a rat. Injection of anesthesia was done intraperitoneally. After anesthetizing the animals, laparotomy with cannulation of the bile duct was carried out. Using this approach, we were able to record the volume of bile at 10, 30 minutes and 3 hours of the acute experiment. Subsequently, concentrations of bile acids in bile were determined by thin-layer chromatography, developed and improved in the Department of General Physiology of the Institute of Physiology named after Academician Petr Bogach of the National Institute of Biology and Medicine of Kyiv National Taras Shevchenko University (Veselsky et al., 1991). By the values of concentrations of conjugated and free choalates, the conjugation and hydroxylation factors of bile acids were calculated.

Statistical data processing was performed using the Statistica 7.0 (StatSoft Inc., USA). The reliability of the differences between the control and experimental groups was estimated by the ANOVA method. The results are also presented as median and upper and lower quartiles $(\mathrm{Me}$ [Q25; Q75]). Statistically significant differences were found for $\mathrm{P}<0.05$.

\section{Results}

In medical practice, in a number of diseases (hypogonadism, infertility, osteoporosis, etc.), testosterone is used intramuscularly in the course of treatment, an approach which we decided to reproduce under experimental conditions on the experimental animals. During intramuscular administration of testosterone $(0.7 \mathrm{mg} / \mathrm{kg})$ to female rats for 5 days, statistically significant changes in the studied characteristics of bile were observed during the whole acute experiment (Fig. 1). In the first halfhour interval, we observed an increase in the secretion of bile to $1.3 \pm$ $0.3 \mu \mathrm{l} / \mathrm{min} \cdot \mathrm{g}$ of liver, i.e. by $128.2 \%(\mathrm{P}<0.001)$, in the second by $126.4 \%(\mathrm{P}<0.001)$ compared to the indicators of the control group of animals. The next half-hour intervals of the acute study were also characterized by a substantially statistically significant increase in the rate of choleresis, namely in the third by $137.1 \%(\mathrm{P}<0.001)$, the fourth by $164.4 \%(\mathrm{P}<0.001)$, fifth by $171.1 \%(\mathrm{P}<0.001)$ and the sixth by $173.2 \%(\mathrm{P}<0.001)$ in comparison with the control parameters (Fig. 1a). The experimental load of testosterone in female rats caused an increase in the level of bile produced by $147.1 \%(\mathrm{P}<0.001)$ compared with the control group (Fig. 1b).

In male rats, there were also statistically significant changes in the rate of choleresis, namely, after 0.5 hour of the acute experiment. In the second, the third, fourth, fifth and sixth intervals of the experiment, choleresis increased by 6.5\% ( $\mathrm{P}<0.05), 11.1 \%(\mathrm{P}<0.01), 20.2 \%(\mathrm{P}<$ $0.001), 21.3 \%(\mathrm{P}<0.001)$ and $20.1 \%(\mathrm{P}<0.001)$ compared to the control group of animals (Fig. 2a). The experimental load of exogenous testosterone on male rats caused an increase in the level of produced bile for all the time of the acute experiment by $12.4 \%(\mathrm{P}<0.01)$ compared with the control group (Fig. $2 b$ ).

Taking into account the fact that secretion of bile in rats is continuous and that, since they do not have a gall bladder, it immediately enters the duodenum, it can be assumed that the volume of allocated liver bile is the result of secretory activity of hepatocytes, and correspondingly, the participation of cholangiocytes in the synthesis of this secretion is less significant compared to other species. This specific feature of rats allows us, according to the dynamics of choleresis activity, to assess the regulatory effects of the hormone used on the external secretion activity of liver cells.
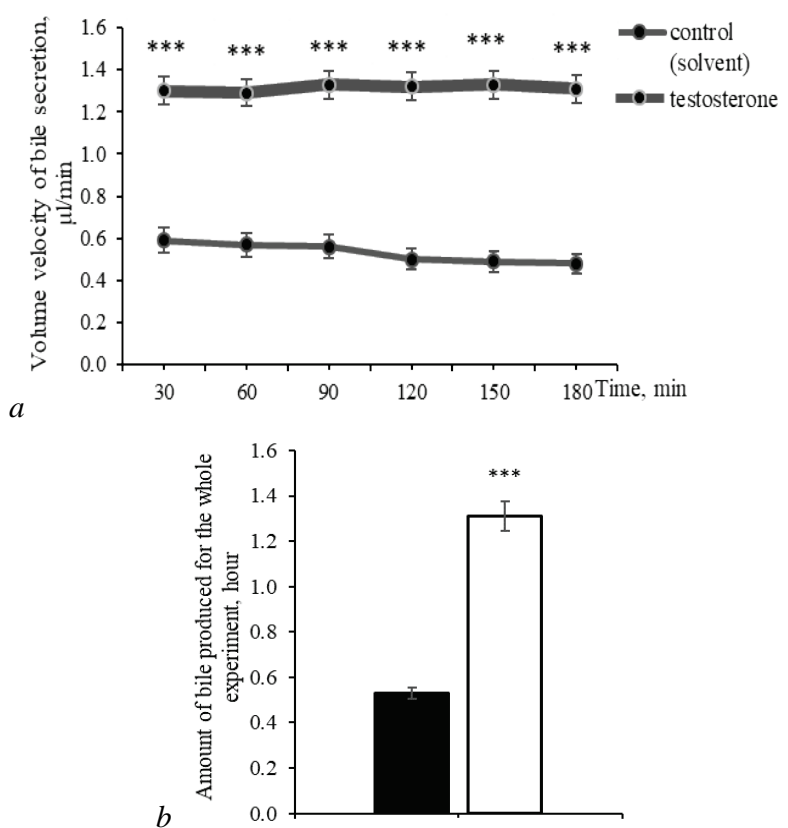

Fig. 1. Volume velocity of bile secretion in female rats in half hour intervals $(a)$ and the amount of bile produced for the whole experiment $(b)$ under control and after intramuscular administration of testosterone propionate $(0.7 \mathrm{mg} / \mathrm{kg}$ ) for 5 days $(\mathrm{x} \pm \mathrm{SD})$ :

*** $-\mathrm{P}<0.001$; black - control (solvent, $\mathrm{n}=11$ ); white - testosterone $(\mathrm{n}=9)$

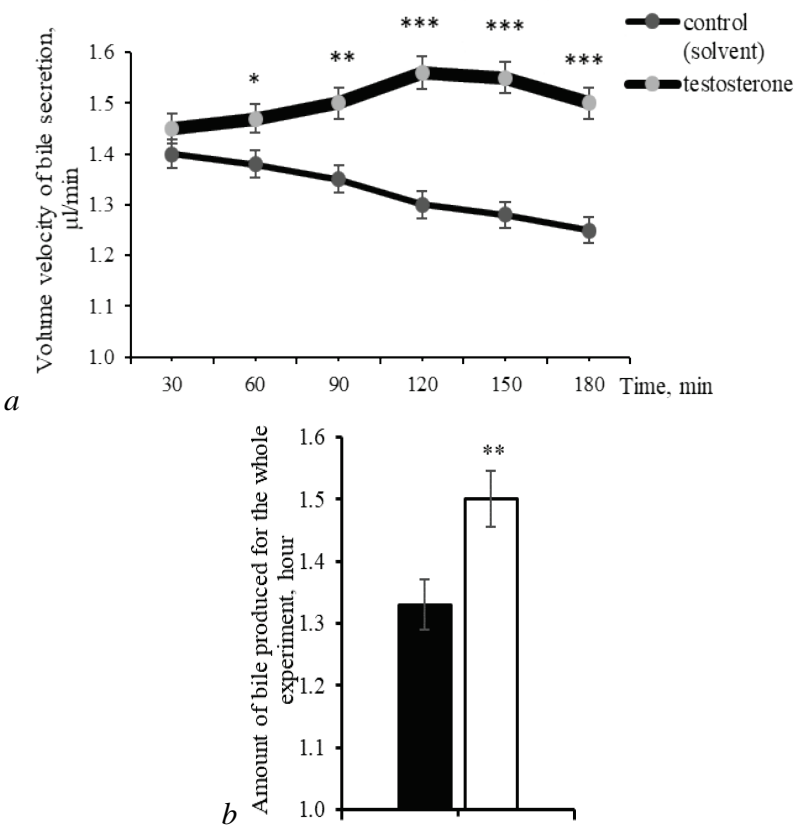

Fig. 2. Volume velocity of bile secretion in male rats at half hour intervals $(a)$ and the amount of bile produced during the whole test $(b)$ in the control and after intramuscular administration of testosterone propionate $(0.7 \mathrm{mg} / \mathrm{kg})$ for 5 days $(\mathrm{x} \pm \mathrm{SD})$ : * $-\mathrm{P}<0.05$, ** $-\mathrm{P}<0.01$, $* * *-\mathrm{P}<0.001$; black - control (solvent, $\mathrm{n}=10$ ), white-testosterone $(n=9)$

The main components of bile are bile acids, which are formed in the liver from cholesterol. In female rats, under influence of testosterone 
propionate, the concentrations of the fractions of conjugated and free bile acids was statistically altered in comparison with the indicators of the control group of animals (Table 1). It turned out that in samples of bile in the studied group of animals, the content of taurocholic acid increased statistically significantly compared to the control after $1.5 \mathrm{~h}$ of acute experiment by $12.5 \%(\mathrm{P}<0.05)$ in the fourth sample of bile, in the fifth by $19.8 \%(\mathrm{P}<0.01)$, the sixth $-27.5 \%(\mathrm{P}<0.001)$. It is the increase in the concentration of taurocholic acid that must reduce the lithogenicity of the bile and the risk of the formation of gallstones (Levadianska et al., 2017; Pasternak et al., 2017). The content of taurochenodeoxycholic and taurodeoxycholic acids in the liver secretion increased only at the end of the experiment by $30.7 \%(\mathrm{P}<0.01)$ compared with the control indicators (Table 1). Concerning glycoconjugates of bile acids, the following is observed: concentration of glycocholic acid in the end of the acute experiment statistically significantly increased in the fifth sample of bile by $31.6 \%(\mathrm{P}<0.01)$, and in the sixth - by $53.9 \%$
( $\mathrm{P}<0.001)$. The content of glycochenodeoxycholic and glycodeoxycholic acids decreased statistically significantly by $39.0 \%(\mathrm{P}<0.001)$ in the first sample of bile, the second by $43.5 \%(\mathrm{P}<0.001)$ in the third $32.6 \%(\mathrm{P}<0.01)$ and in the fourth $-18.2 \%(\mathrm{P}<0.05)$ compared to the values of the control group of animals (Table 1 ).

After the course load on female rats with the studied hormone, significant fractions of free bile acids also occurred. Thus, the concentration of cholic acid statistically significantly increased in the second sample of the liver secretion by $48.2 \%(\mathrm{P}<0.05)$, on the third by $45.1 \%$ $(\mathrm{P}<0.05)$ and the fourth by $37.5 \%(\mathrm{P}<0.05)$ compared to the control group. And the content of chenodeoxycholic and deoxycholic acids in the bile samples of female rats during the entire acute study statistically increased by $45.9 \%(\mathrm{P}<0.05)$ in the first bile test, in the second by $39.5 \%(\mathrm{P}<$ $0.05)$, in the third by $23.3 \%(\mathrm{P}<0.05)$, the fourth by $45.4 \%(\mathrm{P}<0.001)$, in the fifth and sixth samples of the liver secretion by $66.7 \%(\mathrm{P}<0.001)$ and $69.2 \%(\mathrm{P}<0.001)$ compared to the control group of animals (Table 2$)$.

Table 1

Concentration of conjugated bile acids in bile ducts ( $\mathrm{mg} \%$ ) under testosterone ( $\mathrm{n}=9 ; 0.7 \mathrm{mg} / \mathrm{kg}$; injected intramuscularly, over 5 days; $\mathrm{x} \pm \mathrm{SD}$ )

\begin{tabular}{|c|c|c|c|c|c|}
\hline \multirow[b]{2}{*}{$\begin{array}{l}\text { Samples of } \\
\text { bile }\end{array}$} & \multirow[b]{2}{*}{ Series of experiments } & \multicolumn{4}{|c|}{ Fractions of conjugated bile acids } \\
\hline & & taurocholic acid & $\begin{array}{l}\text { taurochenodeoxycholic }+ \\
\text { taurodeoxycholic acid }\end{array}$ & glycocholic acid & $\begin{array}{l}\text { glycochenodeoxycholic }+ \\
\text { glycodeoxycholic acid }\end{array}$ \\
\hline \multirow{2}{*}{1} & control & $177.9 \pm 18.7$ & $98.7 \pm 20.2$ & $92.4 \pm 21.4$ & $36.5 \pm 5.2$ \\
\hline & testosterone & $177.8 \pm 8.6$ & $94.5 \pm 5.7$ & $84.9 \pm 6.7$ & $22.2 \pm 2.8 * * *$ \\
\hline \multirow{2}{*}{2} & control & $177.6 \pm 14.5$ & $98.2 \pm 17.4$ & $91.5 \pm 17.8$ & $36.2 \pm 5.2$ \\
\hline & testosterone & $179.1 \pm 5.3$ & $93.2 \pm 7.5$ & $81.4 \pm 7.6$ & $20.4 \pm 2.1 * * *$ \\
\hline \multirow{2}{*}{3} & control & $171.7 \pm 14.0$ & $95.9 \pm 16.8$ & $90.6 \pm 16.1$ & $34.2 \pm 5.0$ \\
\hline & testosterone & $184.1 \pm 4.8$ & $99.4 \pm 5.9$ & $86.9 \pm 7.2$ & $23.0 \pm 3.0^{* *}$ \\
\hline \multirow{2}{*}{4} & control & $167.3 \pm 14.1$ & $94.3 \pm 14.2$ & $85.3 \pm 17.6$ & $32.4 \pm 4.1$ \\
\hline & testosterone & $189.3 \pm 4.2 *$ & $106.4 \pm 8.1$ & $91.9 \pm 6.0$ & $26.5 \pm 2.8^{*}$ \\
\hline \multirow{2}{*}{5} & control & $163.1 \pm 14.1$ & $93.2 \pm 16.5$ & $81.1 \pm 15.1$ & $29.7 \pm 4.1$ \\
\hline & testosterone & $195.3 \pm 5.1^{* *}$ & $113.6 \pm 8.2$ & $106.6 \pm 6.4^{* *}$ & $30.3 \pm 2.8$ \\
\hline \multirow{2}{*}{6} & control & $159.7 \pm 13.5$ & $90.4 \pm 14.1$ & $77.8 \pm 13.3$ & $27.2 \pm 4.1$ \\
\hline & testosterone & $203.6 \pm 7.7 * * *$ & $118.1 \pm 7.8^{* *}$ & $119.8 \pm 10.7^{* * *}$ & $33.0 \pm 3.1$ \\
\hline
\end{tabular}

Notes: $*_{-} \mathrm{P}<0.05 ; * *-\mathrm{P}<0.01 ; * * *-\mathrm{P}<0.001$ statistically significant differences compared with the control group.

\section{Table 2}

Concentration of free bile acids in bile ducts $(\mathrm{mg} \%)$ under influence of testosterone $(\mathrm{n}=9 ; 0.7 \mathrm{mg} / \mathrm{kg}$; injected intramuscularly, over 5 days; $\mathrm{x} \pm \mathrm{SD}$ )

\begin{tabular}{cllc}
\hline \multirow{2}{*}{$\begin{array}{c}\text { Samples } \\
\text { of bile }\end{array}$} & \multicolumn{1}{c}{$\begin{array}{c}\text { Series of } \\
\text { experiments }\end{array}$} & cholic acid & $\begin{array}{c}\text { Fractions of free bile acids } \\
\text { chenodeoxycholic }+ \\
\text { deoxycholic acid }\end{array}$ \\
\cline { 3 - 4 } 1 & control & $16.8 \pm 3.7$ & $8.2 \pm 1.9$ \\
& testosterone & $23.8 \pm 5.8$ & $12.0 \pm 2.2^{*}$ \\
2 & control & $16.3 \pm 3.1$ & $7.7 \pm 1.0$ \\
& testosterone & $24.2 \pm 5.0^{*}$ & $10.7 \pm 1.7^{*}$ \\
3 & control & $15.3 \pm 3.1$ & $7.9 \pm 1.1$ \\
& testosterone & $22.1 \pm 4.5^{*}$ & $9.7 \pm 0.8^{*}$ \\
4 & control & $14.7 \pm 2.6$ & $7.6 \pm 1.0$ \\
& testosterone & $20.2 \pm 3.9^{*}$ & $11.0 \pm 1.1^{* * *}$ \\
\multirow{2}{*}{5} & control & $15.3 \pm 2.8$ & $7.5 \pm 1.0$ \\
& testosterone & $17.7 \pm 3.5$ & $12.6 \pm 0.8^{* * *}$ \\
6 & control & $15.7 \pm 2.7$ & $7.9 \pm 1.4$ \\
& testosterone & $15.8 \pm 3.5$ & $13.4 \pm 2.0^{* * *}$ \\
\hline
\end{tabular}

Notes: see Table 1.

In male rats which received testosterone propionate at the same dose as that of females, the concentration of bile acids statistically altered, namely: taurocholic, taurochenodeoxycholic and taurodeoxycholic, glycocholic, glycochenodeoxycholic and glycodeoxycholic (Table 3) and cholic (Table 4). The concentration of taurocholic acid increased throughout the acute experiment. In the first half-hour of the bile test, its content increased by $25.9 \%(\mathrm{P}<0.001)$ compared with control values. During the next 2.5 hours of the experiment, the concentration of taurocholic acid increased in a wavelike manner by $24.3 \%(\mathrm{P}<0.001)$, $23.1 \%$ ( $\mathrm{P}<0.001), 25.4 \%$ ( $\mathrm{P}<0.001), 24.6 \%(\mathrm{P}<0.001), 25.2 \%(\mathrm{P}<$ $0.001)$ in comparison with the values of the control group of animals (Table 3). Statistically significant changes were observed in the concentration of taurochenodeoxycholic and taurodeoxycholic acids. Significant changes were noticeable in the beginning of the acute experiment and after 1.5 hours. In particular, their content under the action of the hormone increased by $17.4 \%(\mathrm{P}<0.05)$ in the first sample of the test sample, and in the second by $13.2 \%(\mathrm{P}<0.05)$ compared with the control parameters. After 1.5 hours of experiment, namely the fourth sample of liver secretion, the content of these acids increased by $31.5 \%$ $(\mathrm{P}<0.05)$ compared with the control group of animals (Table 3 ).

Concerning concentration of glycocholic acid, statistically significant changes were observed only in the third and fourth samples of bile, that is, after 1 hour of acute experiment. The content of the investigated fraction in these samples increased by $10.2 \%(\mathrm{P}<0.05)$ compared with the control values. Statistically significant changes were observed throughout the experiment in concentrations of glycogenodeoxycholic and glycodeoxycholic acids. Their content in the studied samples of bile increased in a wavelike manner, namely $83.5 \%(\mathrm{P}<0.001)$ in the beginning of the experiments and $16.8 \%(\mathrm{P}<0.001)$ in the end of the acute experiment (Table 3 ). It should be noted that the course of testosterone in female rats resulted in a decrease in the concentration of glycogenodeoxycholic and glycodeoxycholic acids compared with control (Table 1). Only one fraction of free bile acids of the two studied underwent significant changes (Table 4).

Concentration of cholic acid changed statistically significantly throughout the experiment. In the beginning of the experiment, its content decreased by $38.6 \%(\mathrm{P}<0.01)$, and in the end of the acute experiment $48.5 \%$ ( $\mathrm{P}<0.001)$ compared with the control indicators (Table 4). However, the concentration of cholic acid significantly increased in female rats under the influence of testosterone (Table 2).

The ratio of various components of bile, in particular, various bile acids are of great importance in the pathogenesis of many diseases of the hepatobiliary system. The conjugation indexes (the ratio of the sum of conjugated cholates to the amount of free ones) and hydroxylation (the ratio of the sum of trihydroxycholate bile acids to the sum of dihydroxycholate bile acids) are calculated by the concentrations of conjugated and free bile acids. In our experiment, testosterone in male rats did not cause statistically significant changes in the ratio of conjugated bile 
acids to free ones. And, in the bile which was collected within an hour after the cannulation of the bile duct, the hydroxylation index increased statistically significantly by $13.9 \%(\mathrm{P}<0.05)$, indicating the stimulation of the biotransformation of dihydroxycholate acids to trihydroxycholate. In the following bile samples, no significant changes in the hydroxylation factor have been detected until the end of the experiment (Table 5).

Table 3

Concentration of conjugated bile acids in bile of male rats $(\mathrm{mg} \%)$ under testosterone $(\mathrm{n}=9,0.7 \mathrm{mg} / \mathrm{kg}$, injected intramuscularly, for 5 days, $\mathrm{x} \pm \mathrm{SD})$

\begin{tabular}{|c|c|c|c|c|c|}
\hline \multirow[b]{2}{*}{$\begin{array}{l}\text { Samples } \\
\text { of bile }\end{array}$} & \multirow[b]{2}{*}{$\begin{array}{c}\text { Series of } \\
\text { experiments }\end{array}$} & \multicolumn{4}{|c|}{ Fractions of conjugated bile acids } \\
\hline & & taurocholic acid & $\begin{array}{l}\text { taurochenodeoxycholic }+ \\
\text { taurodeoxycholic acid }\end{array}$ & glycocholic acid & $\begin{array}{l}\text { glycogenodeoxycholic }+ \\
\text { glycodeoxycholic acid }\end{array}$ \\
\hline \multirow{2}{*}{1} & control & $180.8 \pm 11.8$ & $103.1 \pm 8.2$ & $141.8 \pm 13.8$ & $23.6 \pm 6.2$ \\
\hline & testosterone & $227.7 \pm 19.9 * * *$ & $120.7 \pm 15.1^{*}$ & $153.0 \pm 12.4$ & $43.2 \pm 5.9 * * *$ \\
\hline \multirow{2}{*}{2} & control & $179.1 \pm 10.1$ & $104.5 \pm 8.4$ & $144.0 \pm 8.4$ & $21.9 \pm 4.5$ \\
\hline & testosterone & $222.6 \pm 14.7 * * *$ & $118.3 \pm 13.3^{*}$ & $154.1 \pm 10.2$ & $44.6 \pm 5.5^{* * *}$ \\
\hline \multirow{2}{*}{3} & control & $175.7 \pm 9.6$ & $99.8 \pm 8.5$ & $137.2 \pm 9.1$ & $20.8 \pm 5.0$ \\
\hline & testosterone & $216.1 \pm 14.1 * * *$ & $127.1 \pm 33.5$ & $150.9 \pm 10.0^{*}$ & $43.6 \pm 6.0 * * *$ \\
\hline \multirow{2}{*}{4} & control & $173.0 \pm 9.9$ & $95.9 \pm 10.3$ & $132.5 \pm 11.6$ & $19.1 \pm 4.1$ \\
\hline & testosterone & $216.3 \pm 15.6^{* * *}$ & $126.1 \pm 33.3^{*}$ & $146.0 \pm 10.5^{*}$ & $38.8 \pm 5.5^{* * *}$ \\
\hline \multirow{2}{*}{5} & control & $166.0 \pm 1.0$ & $92.7 \pm 9.6$ & $122.7 \pm 16.1$ & $20.4 \pm 4.2$ \\
\hline & testosterone & $206.9 \pm 12.5^{* * *}$ & $118.9 \pm 31.0$ & $136.5 \pm 7.8$ & $41.9 \pm 6.2 * * *$ \\
\hline \multirow{2}{*}{6} & control & $160.2 \pm 10.5$ & $89.6 \pm 7.9$ & $122.1 \pm 16.0$ & $17.4 \pm 3.7$ \\
\hline & testosterone & $200.6 \pm 12.6^{* * *}$ & $111.9 \pm 32.3$ & $136.1 \pm 8.7$ & $37.8 \pm 5.1 * * *$ \\
\hline
\end{tabular}

Notes: see Table 1.

\section{Table 4}

Concentration of free bile acids in bile of male rats $(\mathrm{mg} \%)$ under testosterone ( $\mathrm{n}=9,0.7 \mathrm{mg} / \mathrm{kg}$, injected intramuscularly, for 5 days, $\mathrm{x} \pm \mathrm{SD}$ )

\begin{tabular}{clcc}
\hline \multirow{2}{*}{$\begin{array}{c}\text { Samples } \\
\text { of bile }\end{array}$} & \multicolumn{1}{c}{$\begin{array}{c}\text { Series of } \\
\text { experiments }\end{array}$} & cholic acid & $\begin{array}{c}\text { Fractions of free bile acids } \\
\text { chenodeoxycholic }+ \\
\text { deoxycholic acid }\end{array}$ \\
\hline \multirow{2}{*}{1} & control & $19.9 \pm 4.8$ & $8.3 \pm 2.0$ \\
& testosterone & $12.2 \pm 1.8^{* *}$ & $8.5 \pm 0.8$ \\
\multirow{2}{*}{2} & control & $19.8 \pm 4.3$ & $7.9 \pm 1.3$ \\
& testosterone & $11.6 \pm 2.6^{* * *}$ & $8.6 \pm 0.7$ \\
\multirow{2}{*}{3} & control & $18.9 \pm 4.5$ & $7.5 \pm 1.2$ \\
& testosterone & $11.0 \pm 2.3^{* *}$ & $8.5 \pm 1.2$ \\
\multirow{2}{*}{4} & control & $18.5 \pm 4.2$ & $7.4 \pm 1.1$ \\
& testosterone & $10.6 \pm 1.7^{* * *}$ & $7.9 \pm 1.1$ \\
5 & control & $18.7 \pm 3.8$ & $7.4 \pm 0.8$ \\
& testosterone & $9.7 \pm 1.2^{* * *}$ & $7.7 \pm 0.8$ \\
\multirow{2}{*}{6} & control & $18.3 \pm 3.2$ & $7.4 \pm 0.8$ \\
& testosterone & $9.4 \pm 1.4^{* * *}$ & $7.8 \pm 0.9$ \\
\hline
\end{tabular}

Notes: see Table 1.

\section{Table 5}

Bile acid conjugation factor and hydroxylation factor in bile of female rats under testosterone $(0.7 \mathrm{mg} / \mathrm{kg}$, injected intramuscularly; $\mathrm{mg} \% ; \mathrm{n}=9$ )

\begin{tabular}{clcc}
\hline $\begin{array}{c}\text { Samples } \\
\text { of bile }\end{array}$ & \multicolumn{1}{c}{$\begin{array}{c}\text { Series of } \\
\text { experiments }\end{array}$} & Conjugation factor & Hydroxylation factor \\
\hline \multirow{2}{*}{1} & control & $17.2 \pm 5.9$ & $2.0 \pm 0.2$ \\
& testosterone & $11.0 \pm 2.8$ & $2.2 \pm 0.1$ \\
2 & control & $17.6 \pm 5.1$ & $2.0 \pm 0.2$ \\
& testosterone & $11.0 \pm 2.4$ & $2.3 \pm 0.1^{*}$ \\
\multirow{2}{*}{3} & control & $16.8 \pm 5.5$ & $1.9 \pm 0.3$ \\
& testosterone & $12.6 \pm 2.4$ & $2.2 \pm 0.1$ \\
4 & control & $17.7 \pm 4.9$ & $2.0 \pm 0.1$ \\
& testosterone & $13.5 \pm 2.4$ & $2.1 \pm 0.1$ \\
\multirow{2}{*}{5} & control & $16.7 \pm 5.0$ & $2.0 \pm 0.2$ \\
& testosterone & $14.9 \pm 2.2$ & $2.0 \pm 0.1$ \\
6 & control & $16.0 \pm 5.0$ & $2.0 \pm 0.1$ \\
& testosterone & $16.0 \pm 2.4$ & $2.1 \pm 0.1$ \\
\hline
\end{tabular}

Notes: see Table 1

The conjugation factor under testosterone statistically significantly increased in male rats in the end of the acute test, i.e. in the fifth and sixth samples by $44.2 \%(\mathrm{P}<0.05)$ and $57.9 \%(\mathrm{P}<0.05)$ comparative with control. The increase in this factor indicates the activation of binding processes of free bile acids with taurine and glycine. The hydroxyllation coefficient also increased statistically significantly after 30-minutes of the acute test at $1.8-6.5 \%(\mathrm{P}<0.05)$ (Table 6$)$.
Table 6

Bile acid conjugation factor and male bile hydroxylation in bile under testosterone $(0.7 \mathrm{mg} / \mathrm{kg}$, injected intramuscularly, $\mathrm{mg} \%, \mathrm{Me}\left[\mathrm{Q}_{25} ; \mathrm{Q}_{75}\right], \mathrm{n}=9$ )

\begin{tabular}{clll}
\hline $\begin{array}{c}\text { Samples } \\
\text { of bile }\end{array}$ & \multicolumn{1}{c}{$\begin{array}{c}\text { Series of } \\
\text { experiments }\end{array}$} & $\begin{array}{c}\text { Conjugation } \\
\text { factor }\end{array}$ & $\begin{array}{c}\text { Hydroxylation } \\
\text { factor }\end{array}$ \\
\hline \multirow{2}{*}{1} & control & $22.2 \pm 7.1$ & $2.4[2.4 ; 2.4]$ \\
& testosterone & $26.9 \pm 5.9$ & $2.3[2.2 ; 2.4]^{*}$ \\
\multirow{2}{*}{2} & control & $22.7 \pm 8.7$ & $2.5[2.4 ; 2.5]$ \\
& testosterone & $27.4 \pm 6.0$ & $2.3[2.2 ; 2.3]^{*}$ \\
\multirow{2}{*}{3} & control & $22.9 \pm 8.0$ & $2.5[2.4 ; 2.6]$ \\
& testosterone & $28.4 \pm 6.1$ & $2.3[2.1 ; 2.4]^{*}$ \\
\multirow{2}{*}{4} & control & $22.5 \pm 7.8$ & $2.6[2.5 ; 2.6]$ \\
& testosterone & $29.4 \pm 6.2$ & $2.2[2.1 ; 2.4]^{*}$ \\
\multirow{2}{*}{5} & control & $20.3 \pm 7.0$ & $2.5[2.4 ; 2.7]$ \\
& testosterone & $29.3 \pm 4.8^{*}$ & $2.2[2.2 ; 2.3]^{*}$ \\
\multirow{2}{*}{6} & control & $18.2 \pm 5.6$ & $2.6[2.5 ; 2.7]$ \\
& testosterone & $28.7 \pm 4.9^{*}$ & $2.3[2.2 ; 2.5]^{*}$ \\
\hline
\end{tabular}

Notes: see Table 1.

Consequently, the course load of testosterone propionate in male and female rats resulted in a different effect of this hormone on the external secretion of the liver. This is primarily due to the different density of androgen receptors in the above-mentioned animals and, accordingly, the biotransformation of testosterone in the intramuscular administration, since it is known that the effects of steroid hormones are manifested not only for several hours but even days after their administration.

\section{Discussion}

Under the influence of exogenous testosterone, changes in the bile of male and female rats were observed, mainly increase in the concentrations of the main bile acid fractions, with the exception of glycochenodeoxycholic and glycodeoxycholic acid in females and cholic acid in males - their concentrations decreased compared to the control animals. Cholates regulate transport processes in liver cells at the transcription level of membrane transport proteins while interacting with nuclear hormonal receptors (Synelnyk et al., 2003). Regulatory substances that are capable of affecting the formation and secretion of bile acids can affect various levels of bile-acidic metabolism and transportation of organic constituents of bile. Taking into account that taurocholic acid reduces the risk of gallstone disease (Pasternak et al., 2017), the results may indicate the ability of the test hormone to reduce the lithogenicity of bile. And, the increase in the level of free cholic acid in bile, as observed in female rats, is primarily due to the lower efficiency of the work of the enzymes of this gender, which is responsible for its conjugation with taurine and glycine (Danchenko et al., 2014). One of the integrative indi- 
cators of the coherent functioning of metabolic systems of transformations and transportation of bile acids, especially in hepatocytes, is the conjugation factor. It provides information on the solubilizing properties of bile, and the ratio of free and conjugated bile acid fractions is one of the criteria for assessing the lithogenicity of bile (Athamnah et al., 2015).

In our experiment, the conjugation rate in female rats did not undergo significant changes, whereas in males it significantly increased in the end of the acute experiment. Differences in the results may indicate that in males, the concentration of cholic acid during the acute experiment was statistically significantly reduced compared to the control group of animals. Stimulating the conjugation processes with high-polar compounds such as taurine and glycine also points to the enhancement of one of the methods of biological transformation of endo- and exogenous compounds. And, consequently, it may be an indication of improving the detoxification function of the liver (Reshetnik, 2012).

The bile acid hydroxylation coefficient of bile acids in male rats was significantly reduced, indicating that the test dose of testosterone promotes not only the activation of the poly-enzyme systems that provide conjugation of bile acids, but also increases their biosynthesis by "acidic" with the involvement of mitochondrial enzymes. The latter is associated with hormone activation of processes of tissue respiration in the liver (Borovets et al., 2016). An increase in the abovementioned ratio has been observed in female rats, in two bile samples, which may indicate the stimulatory effect of testosterone on the enzyme systems of liver cells, which provide hydroxylation of dioxocholanic bile acids in hepatocytes, as well as enhancement of the synthesis of trihydroxycholates. Thus, the study of the effect of testosterone on the content of cholates in bile provides the ability to establish the main links of bile formation, on which this hormone exhibits its regulatory effect. In addition, by changing the secretion of bile acids, the regulatory compound can be mediated through these same cholates, as through powerful endogenous cholic secretion regulators, and affect the bile-forming function of the liver of different sexes.

\section{Conclusions}

Testosterone propionate, when administered intramuscularly to male and female rats, significantly changed the concentration of bile acid in the bile, which may indicate its involvement in metabolic transformations and transport of cholates to the primary bile duct tubules.

In female rats, under the action of testosterone, there was an increase in biosynthesis processes of trihydroxycholate and certain dihydroxycholate bile acids in the liver. At the same time, the conjugation index did not undergo significant changes, and the hydroxylation factor increased, indicating a more pronounced synthesis of bile acids by the "classical" route, the key enzymatic reaction of which is the $7 \alpha$-hydroxylation of cholesterol with the participation of CYP7A1.

The concentration of conjugated cholates in male rats, with the introduction of exogenous testosterone, increased significantly. The multidirectional effect of the hormone was on free bile acids, in particular the concentration of cholic acid dropped sharply, indicating the activation of the poly-enzyme systems that ensure its conjugation with glycine and taurine.

\section{References}

Atamnah, S., Reshetnik, J., Levadjans'ka, J., Baranovs'kyj, V., Vesel's'kyj, S., \& Janchuk, P. (2015). Vplyv serotoninu na kon'jugaciju ta gidroksyljuvannja zhovchnyh kyslot u pechinci shhuriv [Serotonin effects on conjugation and hydroxylation of bile acid in the rats liver]. Naukovyj Visnyk Shidno-Jevropejs'kogo Universytetu Imeni Lesi Ukrai'nky, 2, 124-127 (in Ukranian).

Bhandarkar, N. S., Kumar, S. A., Martin, J., Brown, L., \& Panchal, S. K. (2018). Attenuation of metabolic syndrome by EPA/DHA ethyl esters in testosterone-deficient obese rats. Marine Drugs, 16(6), e182.

Borovec', O., Bened', V., Reshetnik, J., Vesel's'kyj, S., \& Makarchuk, M. (2016). Zhovchnosekretorna funkcija pechinky samok shhuriv v umovah blokady estrogenovyh receptoriv tamoksyfenom [Bile secretion liver function in the female rats at estrogen receptor tamoxifen blockade conditions]. Naukovyj Visnyk Shidno-Jevropejs'kogo Universytetu Imeni Lesi Ukrai'nky, 7, 194 199 (in Ukranian).

Boyer, J. L. (2013). Bile formation and secretion. Comprehensive Physiology, 3(3), 1035-1078.

Chernuha, I. S., Reshetnik, Y. M., \& Vesel's'kyy, S. P. (2017). Doslidzhennja lipidnogo skladu zhovchi riznoi' stati pry dii' testosterone [Investigation of lipid composition of bile in different sexes rats under the testosterone influence]. ScienceRise: Biological Science, 4(7), 8-12 (in Ukranian).

Danchenko, N. M., Vesel's'kyj, S. P., \& Cudzevych, B. O. (2014). Spivvidnoshennja zhovchnyh kyslot u zhovchi shhuriv za umov rozvytku aloksanindukovanogo cukrovogo diabetu [Correlations of bile acids in the bile of rats in conditions of alloxan induced diabetes melitus]. Ukrai'ns'kyj Biohimichnyj Zhurnal, 86(6), 147-153 (in Ukranian).

Gerbina, N. A., Ruban, O. A., Kutsenko, S. A., \& Hontovaya, T. N. (2017). Perspektyvy zastosuvannja likars'koi' roslynnoi' syrovyny ta efirnyh olij pry patologijah biliarnogo traktu [Prospects of using medicinal herbs and essential oils for the treatment of the biliary tract]. Chasopys Fitoterapija, 1, 8-16 (in Ukranian).

Klymjuk, O., Bondzyk, O., Vesel's'kyj, S., \& Makarchuk, M. (2010). Vplyv estronu na zovnishn'osekretornu funkciju pechinky shhuriv [Influence of estrone on the external secretion function of the liver of rats]. Visnyk Kyyivs'koho Natsional'noho Universytetu Imeni Tarasa Shevchenka, 56, 59-61 (in Ukranian).

Lee, S. R., Lee, S. Y., Kim, S. Y., Ryu, S. Y., Park, B. K., \& Hong, E. J. (2017). Hydroxylation and sulfation of sex steroid hormones in inflammatory liver. Journal Biomedical Research, 31(5), 437-444.

Levadjans'ka, J., Reshetnik, J., Vesel's'kyj, S., \& Janchuk, P. (2017). Zhovchnokyslotnyj spektr zhovchi samciv shhuriv pry dii' L-cystei'nu [Spectrum of bile acids in the bile of male rats after the administration of L-cysteine]. Naukovyj Visnyk Shidno-Jevropejs'kogo Universytetu Imeni Lesi Ukrai'nky, 7, 221-226 (in Ukranian).

Mintziori, G., Poulakos, P., Tsametis, C., \& Goulis, D. G. (2017). Hypogonadism and non-alcoholic fatty liver disease. Minerva Endocrinologica, 42(2), 145-150.

Novacek, G. (2006). Gender and Gallstone disease. Wiener Medizinische Wochenschrift, 156(19-20), 527-533.

Ohshima, A., Cohen, B. I., Ayyad, N., \& Mosbach, E. H. (1996). Effect of a synthetic androgen on biliary lipid secretion in the female hamster. Lipids, 31(8), 879-886.

Palmisano, B. T., Zhu, L., Eckel, R. H., \& Stafford, J. M. (2018). Sex differences in lipid and lipoprotein metabolism. Molecular Metabolism, 45-55.

Pasternak, A., Bugajska, J., Szura, M., Walocha, J. A., Matyja, A., Gajda, M., Sztefko, K., \& Gil, K. (2017). Biliary polyunsaturated fatty acids and telocytes in Gallstone disease. Cell Transplant, 26(1), 125-133.

Reshetnik, J. (2012). Vplyv blokady opioidnyh receptoriv na spivvidnoshennja holativ u zhovchi shhuriv iz eksperymentalnymalkogolnym gepatytom [Effect of opioid receptor blockade on the relation of cholates in bile of rats with experimental alcoholic hepatitis]. Tavrycheskyj Medyko-Byologycheskyj Vestnik, 15(3), 280-282 (in Ukranian).

Rozen, V. B., Mataradze, G. D., Smyrnova, O. B., \& Smyrnov, A. N. (1991). Polovaja dyfferencyrovka funkcyj pecheny [Gender differentiation of liver function]. Medycyna, Moscow (in Russian).

Schirmer, B. D., Winters, K. L., \& Edlich, R. F. (2005). Cholelithiasis and cholecystitis. Journal of Long-Term Effects of Medical Implants, 15(3), 329-338.

Synel'nyk, T. B., Synel'nyk, O. D., \& Rybal'chenko, V. K. (2003). Zhovchni kysloty $\mathrm{v}$ procesah utvorennja kanal'cevoi' zhovchi [Bile acids the processes of canalicular bile formation]. Fiziologichnyj Zhurnal, 49(6), 80-93 (in Ukranian).

Tomych, M. I. (2015). Docil'nist' vykorystannja gepatoprotektoriv u kompleksnomu likuvanni dobrojakisnyh dysgormonal'nyh dysplazij molochnyh zaloz [Advisability of use of hepatoprotectors is in the treatment dishormonal dysplasia of breast]. Zdorov'e Zhenshhyny, 98, 101-103 (in Ukranian).

Vesel's'kyy, S. P., Lyashchenko, P. S., \& Luk'janenko, Y. A. (1991). Sposob opredelenyja zhelchnyyh kyslot $\mathrm{v}$ byologycheskyh zhydkostjah [A method of determining bile acids in biological fluids]. Avtorskoe Svydetel'stvo 1624322 (in Ukranian).

Wang, H. H., Portincasa, P., \& Wang, D. Q. (2008). Molecular pathophysiology and physical chemistry of cholesterol gallstones. Frontiers in Bioscience, 13(13), 401-423.

Yabiku, K., Nakamoto, K., \& Tokushige, A. (2018). Reintroducing testosterone in the $\mathrm{db} / \mathrm{db}$ mouse partially restores normal glucose metabolism and insulin resistance in a leptin-independent manner. BMC Endocrine Disorders, 18, 38.

Yin, L. J., \& Wang, X. H. (2018). Research advance in the effects of androgen and its receptor on the development of obesity, obesity-related diseases and disorders of glucose and lipid metabolism. Sheng Li Xue Bao, 70(3), 319-328. 